\title{
FRAGMENTS OF HUMAN GROWTH HORMONE PRODUCED BY DIGESTION WITH BROMELAIN
}

\section{CHEMISTRY AND BIOLOGICAL PROPERTIES}

\author{
JOHN B. MILLS ${ }^{a}$, SHARON E. GENNICK ${ }^{\text {b }}$ and JACK L. KOSTYO ${ }^{b}$ \\ a Department of Biochemistry, Emory University School of Medicine, Atlanta, GA 30322 and 'Department of Physiology; The University \\ of Michigan Medical School, Ann Arbor, MI 48109 (U.S.A.)
}

(Received February 22nd, 1982)

(Revised manuscript received August 19th, 1982)

Key words: Growth hormone fragment; Bromelain digestion; (Human)

In an effort to produce small discrete fragments of human growth hormone (GH), we examine the action of the proteolytic enzyme, bromelain, on this molecule. Purified human GH incubated for 40 min at $22^{\circ} \mathrm{C}$ with crude bromelain and gel-filtered on Sephadex G-100 resulted in a major digestion product, peak 2. SDS-urea gel electrophoresis in the presence of $\beta$-mercaptoethanol suggested that peak 2 was composed of two polypeptide chains. Two polypeptide fractions were isolated by the reduction and $S$-alkylation of peak 2 in $6 \mathrm{M}$ guanidine- $\mathrm{HCl}$ and subsequent chromatography on Sephacryl S-200 in $6 \mathrm{M}$ guanidine-HCl. These two fractions, $A$ and $B$, had the same mobilities as the two components of peak 2 on SDS-urea gels. Amino-terminal analysis, tryptic peptide mapping, carboxypeptidase digestion, cyanogen bromide cleavage, and amino acid analysis of fraction $A$ indicated that it was peptide 1-135. Amino-terminal analysis and tryptic peptide mapping of fraction B suggested the presence of a mixture of peptides 143-191, 145-191 and 146-191. Thus, peak 2 is heterogeneous and appears to be a mixture consisting of peptide 1-135 + peptide 143-191, peptide 1-135 + peptide 145-191 and peptide 1-135 + peptide 146-191, in each case the $\mathrm{N}$-terminal peptide being joined to the $\mathrm{C}$-terminal peptide by the disulfide bridge between residues 53 and 165. In the weight-gain test in hypophysectomized rats, two preparations of peak 2 appeared to be somewhat less active than the native human GH preparations from which they were derived. Several preparations of peak 2 showed equivalent potency in stimulating $\mathrm{I}^{14} \mathrm{C}$ /glucose oxidation to ${ }^{14} \mathrm{CO}_{2}$ by isolated epididymal adipose tissue of hypophysectomized rats. Also, most of the peak 2 preparations were somewhat less active than native human GH in displacing ${ }^{125}$ I-labeled human GH bound to antibodies to human GH.

\section{Introduction}

Pituitary growth hormone $(\mathrm{GH})$ possesses several diverse biological properties, i.e., it can be anabolic, diabetogenic, insulin-like and lactogenic (primate GHs) (for a review, see Ref. 1). Analysis

Abbreviation: GH, growth hormone. of the structure-function relationships of the $\mathrm{GH}$ molecule has indicated that the structural determinants for these various activities of the hormone reside in the $\mathrm{N}$-terminal two-thirds of the molecule, since large peptide fragments of this region exhibit weak but definite activity (for reviews, see Refs. 2, 3). The C-terminal third of the molecule, which itself is biologically inert, appears to be essential for the full expression of the activities of 
the hormone. This conclusion is based on the finding that various large biologically inert $S$ carbamidomethylated fragments of the C-terminal third of the human $\mathrm{GH}(\mathrm{GH})$ molecule can be combined noncovalently with $S$-carbamidomethylated peptide $1-134$ of human GH, producing recombinant molecules that possess substantial growth-promoting activity [4-6], diabetogenic activity [6], insulin-like activity [6], lactogenic activity $[7,8]$ and immunoactivity $[5-7]$.

The precise region(s) of the $\mathrm{N}$-terminal portion of the molecule that is responsible for its various activities, and the region(s) of the C-terminal portion of the molecule that is required for the expression of significant activity have not been identified. An approach to the answers to these questions is the production and characterization of recombinant molecules of fragments of the $\mathrm{GH}$ molecule smaller than those used heretofore. The large $\mathrm{N}$ - and $\mathrm{C}$-terminal fragments of the human $\mathrm{GH}$ molecule used in recombination studies to date have been produced by digestion of the molecule with plasmin (EC 3.4.21.7) and thrombin (EC 3.4.21.5) (for a review, see Ref. 2). In an effort to produce smaller discrete fragments of human $\mathrm{GH}$, we have examined the action of the proteolytic enzyme, bromelain (EC 3.4.22.4), on this molecule. Bromelain, which is derived from the stem of the pineapple, was chosen because of its well-known ability to release large peptide fragments from membrane-bound enzymes. In this paper, we describe the partial chemical and biological characterization of a large fragment isolated from bromelain-digested human $\mathrm{GH}$.

\section{Materials and Methods}

Purified human $\mathrm{GH}$ was prepared in our laboratory [9] or was obtained from the National Pituitary Agency (preparation P6). Crude bromelain was purchased from the Sigma Chemical Company, St. Louis, MO. It was purified and assayed as desribed by Murachi [10]. Purified bromelain was coupled to cyanogen bromideactivated Sepharose (Pharmacia Fine Chemicals, Piscataway, NJ) under the conditions recommended by Pharmacia.

Digestion of human GH with conjugated bromelain was carried out by the method de- scribed earlier for the digestion of the hormone with thrombin [2]. The solvent was $0.03 \mathrm{M}$ potassium phosphate, $\mathrm{pH} 7.5$, containing $0.07 \mathrm{M}$ cysteine The activity of our lot (67C-0142) of crude bromelain was about 5500 units $/ \mathrm{mg}$, based upon its caseinolytic activity. For the digestion of human $\mathrm{GH}$ with crude bromelain, the hormone was dissolved at a concentration of $100 \mathrm{mg} / 20 \mathrm{ml}$ in $0.03 \mathrm{M}$ potassium phosphate, $\mathrm{pH} 7.5$, or $0.06 \mathrm{M}$ ammonium bicarbonate containing $0.07 \mathrm{M}$ cysteine or $0.001 \mathrm{M}$ dithiothreitol. The enzyme was present at a concentration of $4 \mathrm{mg} / 20 \mathrm{ml}$. After the desired time at room temperature, the diges. tion mixture was lyophilized.

Salts and small peptides were separated from the major digestion product by gel filtration on Sephadex G-100 as described below. The polypeptide chains of the major product were separated by gel filtration on Sephacryl S-200 in $6 \mathrm{M}$ guanidine- $\mathrm{HCl}$ as described previously [2].

SDS-gel electrophoresis was performed in the presence of $8 \mathrm{M}$ urea as described by Swank and Munkres [11].

For cyanogen bromide cleavage of digestion products, $25 \mathrm{mg}$ of protein and $25 \mathrm{mg}$ of cyanogen bromide were dissolved in $2.5 \mathrm{mi}$ of $70 \%$ formic acid and allowed to stand at room temperature overnight. The mixture was then dried under vacuum, redissolved in $0.15 \mathrm{ml}$ of $70 \%$ formic acid, diluted to $10 \%$ formic acid, and gel-filtered on a $0.9 \times 56 \mathrm{~cm}$ column of Sephadex G-75. The retarded fraction, consisting of small peptide(s), was submitted to paper electrophoresis at $\mathrm{pH} 6.5$ and 3.5 .

Conditions for paper electrophoresis, peptide mapping, amino-terminal analysis by dansylation and amino acid analysis have been given earlier [12].

The methods used to assess the growth-promoting and insulin-like activities of the digestion products and their abilities to compete with ${ }^{125} \mathrm{I}$ labeled human $\mathrm{GH}$ for binding to antiserum to human GH have been described previously $[2,6]$.

\section{Results and Discussion}

Purified bromelain degraded human $\mathrm{GH}$ to a mixture of small peptides, whether or not the enzyme was conjugated to Sepharose. This ob- 
servation was based upon the behavior of the digestion mixture on gel filtration or peptide maps. However, when similar experiments were conducted using equal caseinolytic units of crude bromelian, the crude enzyme digested the hormone to a more limited extent and generated a large biologically active fragment. This difference between the activities of purified and crude bromelain on human $\mathrm{GH}$ is not clearly understood. It is known [10] that crude bromelain preparations contain an inhibitor which is removed in the purification process. It is possible that removal of this inhibitor is responsible for the modified activity of

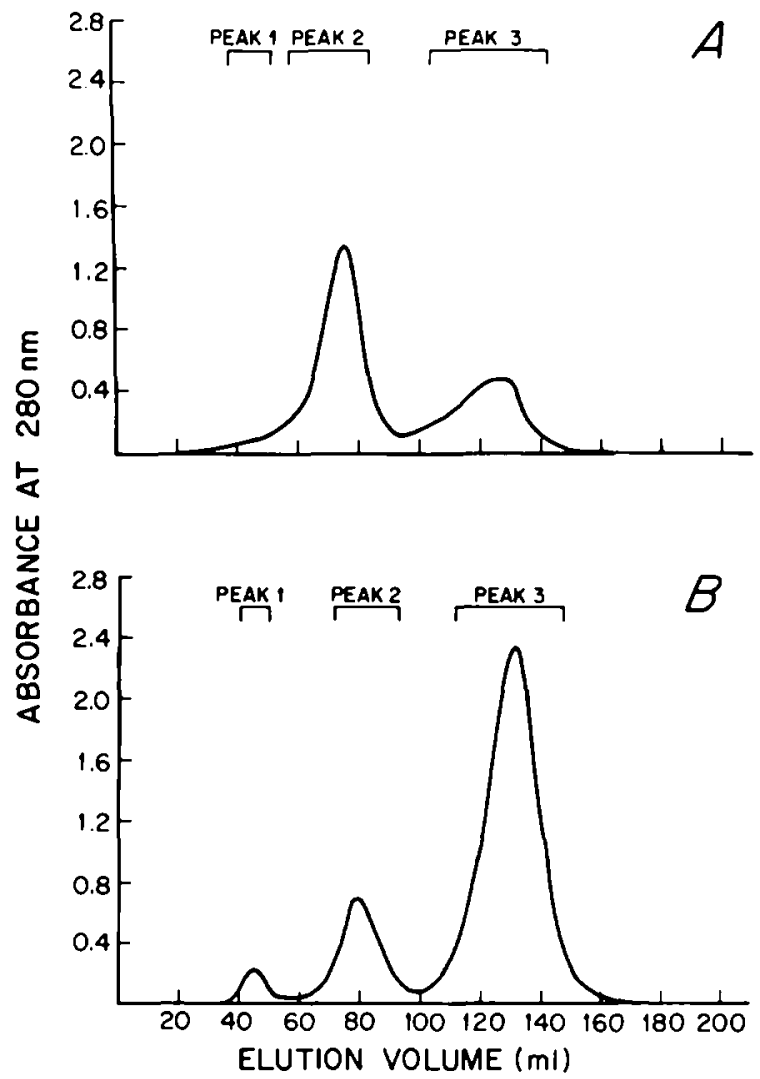

Fig. 1. Gel filtration of bromelain digested human GH. A, Human GH $(48.1 \mathrm{mg})$ was digested with crude bromelain for $40 \mathrm{~min}$ at room temperature and then lyophilized. The lyophilized digest was dissolved in $2 \mathrm{ml}$ of $0.06 \mathrm{M}$ ammonium bicarbonate, applied to a $1.5 \times 84$ column of Sephadex G-100. and eluted with the same buffer at $4^{\circ} \mathrm{C}$. B. Human GH $(95.7$ $\mathrm{mg}$ ) was digested with crude bromelain for $16 \mathrm{~h}$ at room temperature and then lyophilized. The lyophilized digest was then gel-filtered as described for $\mathrm{A}$. the purified enzyme that we observed.

The large biologically active fragment generated by the digestion of human $\mathrm{GH}$ with crude bromelain was isolated from the digestion mixture by gel filtration and appears as peak 2 in Fig. 1. In that figure, peak 1 represents aggregated material, and peak 3 represents small peptides, which have not been characterized. The yield of peak 2 was considerably greater $(60 \%)$ when a 40 -min digestion time was used (Fig. 1A) than with a 16-h (15\%) digestion time (Fig. 1B).

SDS-gel electrophoresis of peak 2 in the presence of $\beta$-mercaptoethanol suggested that it was composed of two polypeptide chains (Fig. 2). Therefore, as a first step in its chemical characterization, peak 2 was treated with dithiothreitol to reduce the disulfide bonds, and it was then $S$-alkylated with iodoacetamide. The product was gelfiltered in the presence of $6 \mathrm{M}$ guanidine- $\mathrm{HCl}$. Two major fractions, A and B, eluted (Fig. 3). The yields of fractions A and B were 55 and $25 \%$ by weight of the starting material, respectively. On SDS-gel electrophoresis, fractions $A$ and B migrated with the same mobilities as the slow and

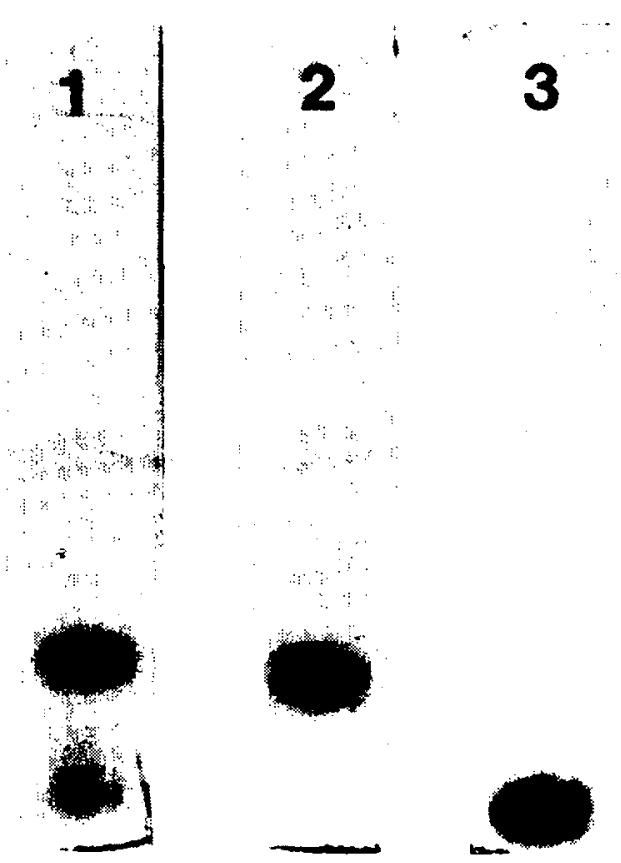

Fig. 2. SDS-gel electrophoresis of $15 \mu \mathrm{g}$ each of peak 2 (1), fraction $A(2)$ and fraction $B(3)$ in the presence of $19(\mathrm{v} / \mathrm{v})$ $\beta$-mercaptoethanol. The anode is at the bottom. 


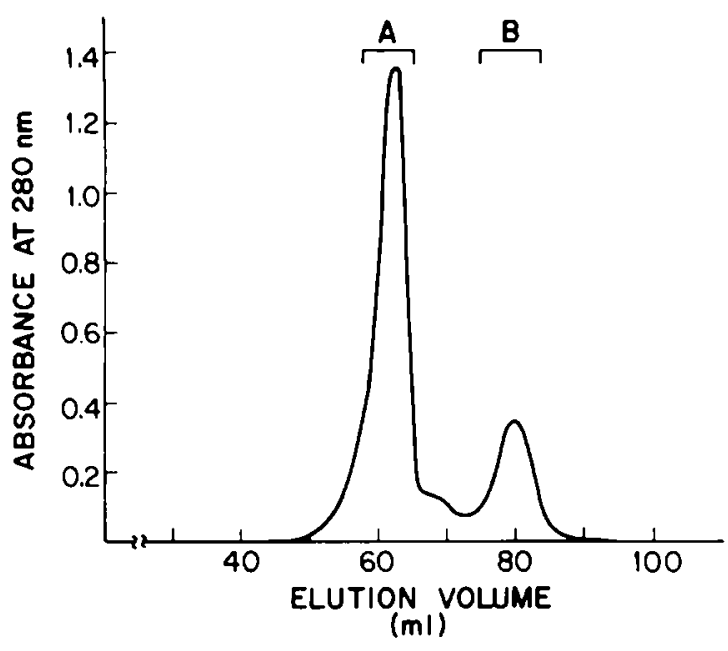

Fig. 3. Gel filtration of reduced and $S$-carbamidomethylated peak 2 . In this experiment $20 \mathrm{mg}$ of peak 2 were reduced with dithiothreitol and $S$-carbamidomethylated with iodoacetamide in buffer consisting of $1.4 \mathrm{M}$ Tris- $\mathrm{HCl} / 6 \mathrm{M}$ guanidine- $\mathrm{HCl}, \mathrm{pH}$ 8.6. The sample was then applied to a $2.5 \times 110 \mathrm{~cm}$ column of Sephacryl S-200 equilibrated with a buffer consisting of $0.01 \mathrm{M}$ Tris- $\mathrm{HCl} / 6 \mathrm{M}$ guanidine- $\mathrm{HCl}, \mathrm{pH} 8.0$, and developed with the same buffer.

fast components, respectively, in peak 2 (see Fig. 2). It can be seen in Fig. 4 that fraction A migrated with the same mobility as peptide $1-134$

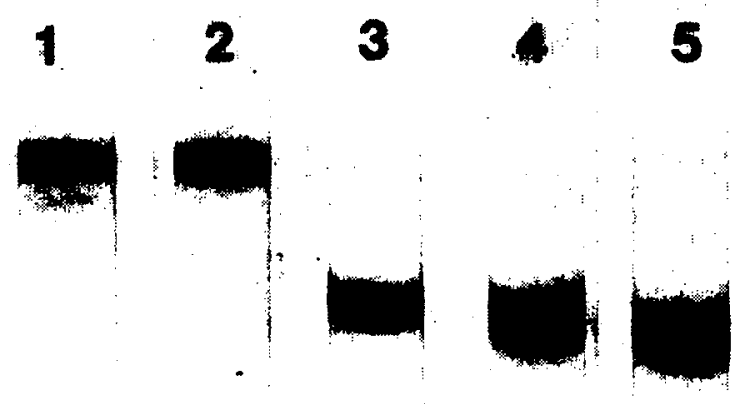

Fig. 4. SDS-gel electrophoresis of $12 \mu \mathrm{g}$ each of peptide $1-134$ of human GH (1), fraction A (2), peptides 135-191 (3) and $|4|-19 \mid(4)$ of human $G H$ and fraction $B(5)$, in the presence of $8 \mathrm{M}$ urea. The anode is at the bottom. prepared from thrombin-digested human GH [2]. Fraction B had a slightly greater mobility than peptide 141-191 derived from plasmin-degraded human GH [6] and peptide 135-191 derived from thrombin-digested human $\mathrm{GH}$ [2].

Amino-terminal analysis of peak 2 by the dansyl procedure revealed phenylalanine, tyrosine and lysine. Amino-terminal analysis of fraction $\mathrm{A}$ indicated only the presence of phenylalanine, whereas phenylalanine, tyrosine and lysine were found as amino-terminal residues in fraction $\mathbf{B}$.

Peptide maps of tryptic digests of fraction $A$ revealed the presence of various peptides in the amino-terminal region of human $\mathrm{GH}$, including peptide 128-134, but not peptide 135-140. Similar maps of fraction $B$ revealed the presence of peptides characteristic of the carboxy terminal region. including peptides 146-158 and 184-191, but peptides $135-140$ and 141-145 were not detected.

Of the peptides isolated after cyanogen bromide cleavage of fraction $A$, only one was successfully isolated by paper electrophoresis. Its amino acid composition corresponded exactly to the calculated composition of peptide 126-135 of human $\mathrm{GH}$, indicating that this peptide represented the carboxy terminus of fraction $\mathrm{A}$. Carboxypeptidase digestion of fraction $\mathrm{A}$ for $2 \mathrm{~h}$ resulted in the release of $0.52 \mathrm{~mol}$ equivalent of threonine (residue 135).

These data suggested that the major product produced by digestion of human $\mathrm{GH}$ with bromelain, peak 2 , is heterogenous and is a mixture consisting of peptide $1-135+$ peptide 143-191, peptide 1-135+ peptide 145-191 and peptide $1-135+$ peptide $146-191$, in each case the $\mathrm{N}$-terminal peptide being joined to the $\mathrm{C}$-terminal peptide by the disulfide bridge between residues 53 and 165 . Accordingly, fraction $B$ is a mixture of peptides 143-191, 145-191 and 146-191. Amino acid analyses of several preparations of fractions $A$ and $B$ are consistent with the above interpretation of the results. One such analysis is given in Table I.

In the weight-gain test in hypophysectomized rats, two preparations of peak 2 appeared to be somewhat less active than the native human $\mathrm{GH}$ preparations from which they were derived (Table II), although it remains to be established whether 
TABLE 1

\section{AMINO ACID COMPOSITION OF FRACTIONS A AND B PREPARED FROM BROMELAIN.DIGESTED HUMAN GH}

Fraction $\mathrm{A}$ found values are means of triplicate analyses of a single preparation: those for fraction $B$ were calculated for a 49-residue peptide.

\begin{tabular}{|c|c|c|c|c|}
\hline \multirow[t]{2}{*}{ Amino acid } & \multicolumn{2}{|c|}{ Fraction A } & \multicolumn{2}{|c|}{ Fraction B } \\
\hline & Found & $\begin{array}{l}\text { Cal- } \\
\text { culated } \\
\text { for } \\
\text { peptide } \\
1-135\end{array}$ & Found & $\begin{array}{l}\text { Cal- } \\
\text { culated } \\
\text { for } \\
\text { peptide } \\
143-191\end{array}$ \\
\hline Asp & 12.6 & 12 & 7.9 & 8 \\
\hline Thr & 6.8 & 7 & 2.0 & 2 \\
\hline Ser & 12.9 & 14 & 3.7 & 5 \\
\hline Glu & 21.9 & 22 & 4.2 & 3 \\
\hline Pro & 7.9 & 8 & trace & 0 \\
\hline Gly & 4.4 & 4 & 3.1 & 3 \\
\hline Ala & 6.0 & 6 & 1.3 & 1 \\
\hline Val & 3.9 & 4 & 2.8 & 3 \\
\hline Met & 2.0 & 2 & 1.0 & 1 \\
\hline Ile & 5.5 & 6 & 1.1 & 1 \\
\hline Leu & 20.9 & 21 & 6.1 & 5 \\
\hline Tyr & 5.0 & 5 & 2.2 & 3 \\
\hline Phe & 7.8 & 8 & 3.5 & 4 \\
\hline His & 2.0 & 2 & 1.0 & 1 \\
\hline Lys & 4.3 & 4 & 3.5 & 4 \\
\hline Arg & 7.8 & 8 & 3.2 & 3 \\
\hline $\begin{array}{l}S \text {-Carboxy- } \\
\text { methyl- } \\
\text { cysteine }\end{array}$ & 0.9 & 1 & 2.8 & 3 \\
\hline
\end{tabular}

TABLE II

GROWTH-PROMOTING POTENCY OF PEAK 2 ISOLATED FROM BROMELAIN-DIGESTED HUMAN GH

Values were estimated in the 9-day weight-gain test in hypophysectomized rats using the International Standard of Growth Hormone, Bovine (1.0 I.U./mg) as the standard.

\begin{tabular}{lll}
\hline Material & \multicolumn{2}{l}{ Growth-promoting potency } \\
\cline { 2 - 3 } & I.U./mg & $\begin{array}{l}(95 \% \\
\text { confidence } \\
\text { limits) }\end{array}$ \\
\hline $\begin{array}{ll}\text { Precursor human GH } \\
\text { (HS2228F) }\end{array}$ & 1.14 & $(0.78-1.55)^{\mathrm{a}}$ \\
$\begin{array}{l}\text { Peak 2 (7M 1206A) } \\
\text { Precursor human GH }\end{array}$ & 0.91 & $(0.48-1.46)^{b}$ \\
(HS2227D) & 1.64 & $(0.73-1.97)^{\mathrm{a}}$ \\
Peak 2 (7M 1243) & 1.17 & $(0.61-1.95)^{b}$ \\
\hline
\end{tabular}

- Pooled estimate from six assays.

b Singe assay.

this apparent attenuation in potency is significant. Several preparations of peak 2 were found to be equivalent in potency to human $\mathrm{GH}$ in stimulating $\left[{ }^{14} \mathrm{C}\right]$ glucose oxidation to ${ }^{14} \mathrm{CO}_{2}$ by isolated epididymal adipose tissue of hypophysectomized rats. Typical results obtained with two peak 2 preparations are shown in Table III. Several preparations of peak 2 were also tested for the ability to displace ${ }^{125}$ I-labeled human $\mathrm{GH}$ bound to antibodies

TABLE III

IN VITRO EFFECTS OF PEAK 2 ISOLATED FROM BROMELAIN-DIGESTED HUMAN GH ON GLUCOSE OXIDATION BY ADIPOSE TISSUE OF HYPOPHYSECTOMIZED RATS

Segments of epididymal adipose tissue were incubated for $60 \mathrm{~min}$ at $37^{\circ} \mathrm{C}$ in medium containing $\left[{ }^{14} \mathrm{C}\right] g$ lucose without or with the indicated concentration of test substance. Concenration was calculated assuming a molecular weight of 22000 for both human $\mathrm{GH}$ and peak 2. Values are mean \pm S.E.

\begin{tabular}{|c|c|c|c|c|}
\hline \multirow[t]{2}{*}{ Material } & \multirow{2}{*}{$\begin{array}{l}\text { Concentration } \\
(\mathrm{nM})\end{array}$} & \multirow{2}{*}{$\begin{array}{l}\text { Number of } \\
\text { rats }\end{array}$} & \multicolumn{2}{|c|}{${ }^{14} \mathrm{CO}_{2}$ production (dpm/mg per $\mathrm{h}$ ) } \\
\hline & & & Control & Hormone \\
\hline \multirow[t]{2}{*}{ Human GH (HS2227D) } & 1 & 8 & $50.0 \pm 8.1$ & $71.3 \pm 10.5$ \\
\hline & 10 & 8 & $50.0 \pm 8.1$ & $102 \pm 12.3$ \\
\hline \multirow[t]{2}{*}{ Peak 2 (7M1158) } & 1 & 8 & $50.0 \pm 8.1$ & $61.2 \pm 6.7$ \\
\hline & 10 & 8 & $50.0 \pm 8.1$ & $107 \pm 14.4$ \\
\hline \multirow[t]{2}{*}{ Human GH (HS2227D) } & 1 & 6 & $31,3 \pm 3.2$ & $41.9 \pm 4.2$ \\
\hline & 10 & 6 & $31.3 \pm 3.2$ & $59.0 \pm 8.7$ \\
\hline \multirow[t]{2}{*}{ Peak 2 (7M1182) } & 1 & 6 & $31.3 \pm 3.2$ & $48.6 \pm 77$ \\
\hline & 10 & 6 & $31.3 \pm 3.2$ & $58.5 \pm 8.3$ \\
\hline
\end{tabular}




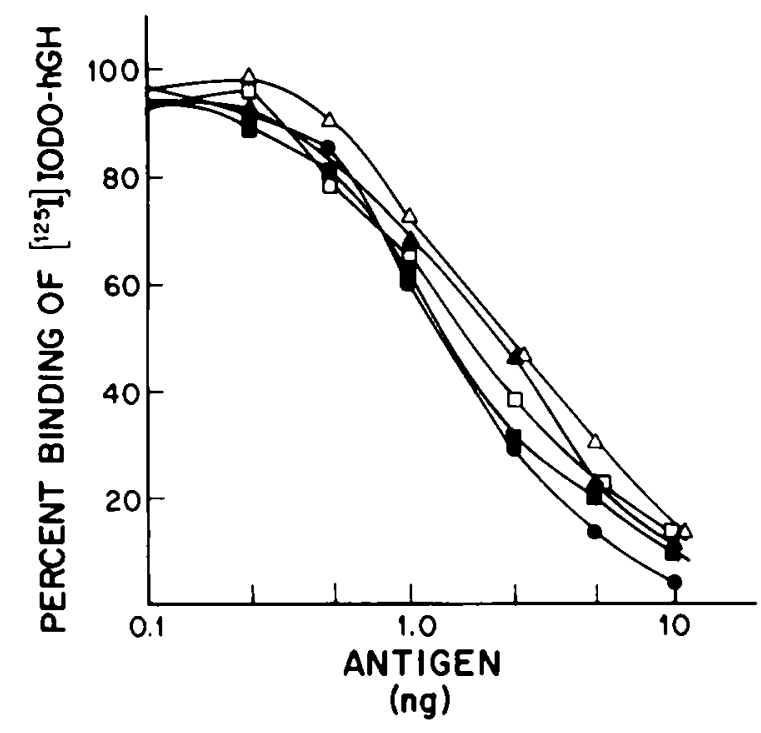

Fig. 5. Displacement curves showing the relative ability of human GH (๑), and several preparations of peak $2(\Delta, 7 \mathrm{M} 1243$; 7M1206A; ․, 7M1182; $4,7 \mathrm{M} 1177)$ to compete with ${ }^{125}$ I-labeled human $\mathrm{GH}$ for binding to antibodies to human $\mathrm{GH}$.

to human GH and were found (Fig. 5) to be on average somewhat less active than native human $\mathrm{GH}$ in this assay.

The above results are of considerable interest, since a significant fraction of the molecules contained in the peak 2 mixture are rather similar in structure to a cleaved form of human GH isolated from human pituitary extracts by Lewis et al. [13]. This cleaved form of human GH, designated $\alpha_{3}$, was found in only small amounts in these extracts and consisted of residues 1-134 connected to residues $147-191$ by the disulfide bond between residues 53 and 165 . It was found by Lewis and his colleagues to possess several times the growthpromoting activity of native human GH. In con- trast, we have found that peak 2 does not possess enhanced growth-promoting activity, and, if anything, it is less active than native human $\mathrm{GH}$ in stimulating growth.

\section{Acknowledgements}

This work was supported by grants from the National Institutes of Health (AM26511) and The Kroc Foundation.

\section{References}

1 Kostyo, J.L. and Reagan, C.R. (1976) in Pharmacology and Therapeutics, B (Li, C.H., ed.), Vol. 2, pp. 591-604, Pergamon Press, New York

2 Mills, J.B., Kostyo, J.L., Reagan, C.R., Wagner, S.A., Moseley, M.H. and Wilhelmi, A.E. (1980) Endocrinology 107. 391-399

3 Russell, J., Sherwood, L.M., Kowalski, K. and Schneider. A.B. (1981) J. Biol. Chem. 256, 296-300

$4 \mathrm{Li}$, C.H. and Bewley, T.A. (1976) Proc. Natl. Acad. Sci. U.S.A. 73, 1476-1479

5 Li, C.H., Bewley, T.A., Blake. J. and Hayashida, T. (1977) Proc. Natl. Acad. Sci. U.S.A. 74, 1016-1019

6 Reagan, C.R. Kostyo. J.L.. Mills. J.B.. Gennick. S.E.. Messina, J.L.. Wagner. S.A. and Wilhelmi. A.E. (1981) Endocrinology 109, 1663-1671

7 Li, C.H., Hayashida. T., Doneen, B.A. and Rao, A.J. (1976) Proc. Natl. Acad. Sci. U.S.A. 73, 3463-3465

8 Russell, J., Sherwood, L.M., Kowalski, K. and Schneider, A.B. (1979) Program of the 61st Meeting of The Endocrine Society, June 1979, Abstract 683

9 Mills, J.B., Ashworth, R.B., Wilhelmi, A.E. and Hartree. A.S. (1969) J. Clin. Endocrinol. Metab. 29. 1456- 1459

10 Murachi, T. (1970) Methods Enzymol. 19, 273-284

11 Swank, R.T. and Munkres, K.D. (1971) Anal. Biochem. 39. 462-477

12 Mills, J.B., Kostyo, J.L., Moseley, M.H., Reagan, C.R. and Wilhelmi, A.E. (1978) Endocrinology 102, 1366-1376

13 Lewis, U.J., Singh, R.N.P., Tutwiler, G.F., Sigel, M.B., VanderLaan, E.F. and VanderLaan. W.P. (1980) Recent Prog. Horm. Res. 36, 477-508 